\title{
The New Constitutional Right to Maintenance in the United States by John Ryskamp
}

The 2003, United States Supreme Court case of Lawrence v. Texas is not a maintenance case. It abolished laws against sodomy. In doing so, however, it overruled the case which prevented a right to maintenance in the United States. In the 1937 case of West Coast Hotel v. Parrish, the Supreme Court, although sustaining a minimum wage law, nevertheless did so on the sole basis of demoting liberty (supposed by the Court to forbid minimum wage laws) to an unenforceable interest. The notion of an unenforceable interest was part of the scrutiny regime established in West Coast Hotel. The regime said that most facts-including maintenance-were subject to government discretion as long as that discretion was rationally related to a legitimate government interest. This, the Court felt, was necessary in order to rein in liberty.

Lawrence $v$. Texas has ended that regime by finding an individually enforceable right to liberty, elevating it from its previously unenforceable status as an interest. We currently have no idea what standard the United States Government must meet in order to violate the new individually enforceable right to liberty. However, the scrutiny regime has clearly been abolished because its basis - the demotion of liberty to an unenforceable interest-has been overruled.

Even as an unenforceable interest, the Supreme Court had prepared the ground for a Constitutional reevaluation of maintenance in a case pursuant to West Coast Hotel. In United States v. Carolene Products, the Court sustained a law banning substitute ingredients in milk, on the basis that maintenance is important to health. Nevertheless, in 1989, the Court, in DeShaney v. Winnebago County, found specifically that maintenance was not an individually enforceable right; it based this decision on the idea that liberty had been demoted to an unenforceable interest.

The anomaly - and the larger dispute as to whether liberty ever had anything to do with minimum wage laws or maintenance in the first place-ended with Lawrence $v$. Texas. We are in the same position with respect to maintenance as we are with respect to liberty. The Court has not yet indicated no idea what standard the United States Government must meet in order to violate the new individually enforceable right to maintenance. However, we do know one thing: maintenance is now an individually enforceable right in the United States. This is a profound change in the Constitutional history of the United States which, given the predominance of the United States in world legal policy, will affect the social policies of every other nation.

Even the most cautious commentators recognized that the Supreme Court did something other than simply find the lack of a rational basis for the Texas sodomy law which it declared unconstitutional in Lawrence v. Texas. ${ }^{1}$ Clearly, the Court moved liberty out of minimum scrutiny as an interest, and elevated it to an individually enforceable right. At what level? That seems to be what no one can figure out. Of

\footnotetext{
${ }^{1} 539$ US 558 (2003).
} 
course, the problem with figuring it out is that commentators, litigants and the courts still link liberty to causes of action involving sexuality/the family. The Court did not. The Lawrence right to liberty is simply that: the right to liberty. We don't need to agree on the level of scrutiny it enjoys in every context, in order to realize that it is now a generally applicable right - that is, it trumps other concerns like, if not at the same level as, protected speech and freedom from an establishment of religion.

Part of the problem of understanding Lawrence is that we do not have a clear understanding of the doctrinal basis of minimum scrutiny. For that, we need to reexamine the case which articulated that basis and promulgated the scrutiny regime, West Coast Hotel v. Parrish. ${ }^{2}$ It has not been noted previously that the premise of West Coast Hotel is a "demotion" of liberty from an individually enforceable right to an interest, based on a highly dubious analysis of liberty from a Court frightened that it was about to lose power. It is this "demotion" and this alone, which provides the basis for the scrutiny regime. Thus, when the Court elevated scrutiny once again to an individually enforceable right in Lawrence, it overruled West Coast Hotel, the first time that had happened since the decision was issued in 1937. Lawrence marks the beginning of the end of the scrutiny regime, something which, largely due to the regime's incoherence but also due to the demand of public opinion, has been anticipated. As one commentator has noted:

At one point in its history American constitutional jurisprudence presumed that the distinction between "judicial" and "political" questions was intelligible; at another point it presumed that the boundary between public power and private rights could coherently be traced; at another it presumed that there was a clear difference between the sort of legislation that required heightened and the sort that only required minimal scrutiny. Those presumptions did not come from the Constitution or any other legal source. They came from a set of shared social and political attitudes that shaped conceptions of the role of the judiciary in American constitutionalism. As those attitudes changed, presumptions changed with them. A robust constitutional principle of departmental discretion gave way to judicial boundary tracing which gave way to judicially fashioned levels of scrutiny. None of those regimes of constitutional interpretation should be regarded as cast in stone. None should be regarded as intrinsically superior to the others. The scrutiny regime has been with us for approximately 70 years. It may have exhausted itself as a helpful technique of constitutional interpretation. If we understand its historical origins, perhaps we can understand its contingent status. ${ }^{3}$

The demise of the regime is well under way, even if we are in something of a quandary as to where that leaves us. ${ }^{4}$

West Coast Hotel sustained a state minimum wage law for women and minors. In sustaining the law, the Court stated that "the Constitution does not recognize an absolute and uncontrollable liberty. Liberty in each of its phases has its history and connotation. But the liberty safeguarded is liberty in a social organization which requires the protection of law against the evils which menace the health, safety, morals, and welfare of the people. Liberty under the Constitution is thus necessarily subject to the restraints of due process, and regulation which is reasonable in relation to its subject and is adopted in the interests of the community is due process." 5 The claimed authority for the law was

\footnotetext{
2300 US 379 (1937).

${ }^{3}$ G. Edward White, "Historicizing Judicial Scrutiny," http://law.bepress.com/uvalwps/uva publiclaw/art31, 142.

${ }^{4}$ My own take on the level of scrutiny for liberty post-Lawrence, "The New Constitution: The Eminent Domain Revolt and Its Consequences," http://ssrn.com/abstract=562521.

${ }^{5}$ West Coast Hotel at 391.
} 
merely that "the statute is a reasonable exercise of the police power of the state."6 Nevertheless, the Court felt moved to assume, without deciding, that minimum wage laws were an aspect of due process and that due process conflicted with liberty. It further assumed, again without deciding, that indicia of liberty are

1. absoluteness combined with uncontrollability;

2. "phases;"

3. "history and connotation;" and

4. "evils which menace the health, safety, morals, and welfare of the people."

Where it picked up these bizarre prejudices, no one knows. Adept at describing liberty, the Court felt that the Constitution "does not recognize" liberty as a fact. This nonrecognition was also the recognition of the Court's new "liberty," the indicia of which are

1. regulation

2. reasonably relating to

3. a subject.

And what is the subject? The same one the Constitution "does not recognize." Passing by this anomaly, we ask: for the fact of liberty, the Court substituted what fact? The regime-the "social organization." That is what the Constitution recognized. Where the Court picked up this additional bizarre prejudice, no one knows, either. It is worth noting that the prejudice is a view of the Constitution as pre- or proscriptive, rather than descriptive. It assumes, without deciding, that either liberty or due process is "subject" to the other and assigns the definition of "subject" to another term which is undefined, the "social organization."

Already, the Court has gone so far with unexamined assumptions and simple speculations that the decision would clearly not pass muster in today's legal environment: if it were not precedent, it would never be tolerated by anyone. Politics has intervened to produce a wildly erratic holding. It is ducking and shuffling by a Court on the run from Court-packing-it is nonsensical, evasive, bad faith. Among its other damaging assumptions is that prior to the vindication of the minimum wage law, liberty had somehow been an individually enforceable right. This is another unstated assumption which is nowhere proved or even discussed, except in the context of the Court's statedand equally unsupported-assumptions about liberty. The decision is an unholy mess. Indeed, since there is no reasoned discussion by the Court of liberty in its pre-West Coast state, it is entirely unclear that West Coast "demoted" liberty in the first place or what the Court felt it was "demoting."

What is important to note is that the "demotion"-or whatever the Court is doing-of liberty is the sole basis on which the Court sustains the minimum wage law and establishes the scrutiny regime. Viewed exclusively as a matter of legal technique, the most important aspect of West Coast Hotel is that by "demoting" liberty to an "interest," the Court constructed for itself a "place" to put all facts-among them, maintenance-with which its manifestly limited understanding made it incapable of

${ }^{6} I d$., at 389 . 
coping; the history of the "minimum scrutiny" regime is the history of the Court's progressive refusal to let anyone else deal with such facts, either. For example, minimum scrutiny says that a law must have a rational relation to a legitimate public purpose, but the Court has famously said that the purpose needn't exist in fact. ${ }^{7}$ Its absence as a fact could not be asserted against government's invocation of minimum scrutiny. Clearly, that idea was not going to be tolerable forever, especially given its glaringly problematic basis.

Actually, the unspoken basis of West Coast Hotel was Marbury v. Madison, ${ }^{8}$ which was nowhere mentioned. The law in question in Marbury-which might have permitted the Court to order the Executive to turn over a commission-was clearly unenforceable, not simply because the contemporary Administration might have refused, but also because future Administrations might refuse. How does unenforceability play into West Coast Hotel? The West Coast Hotel Court overruled an earlier case, Adkins v. Children's Hospital, ${ }^{9}$ in which minimum wage laws had been found unconstitutional. Adkins was from 1923; West Coast Hotel was from 1937. What had happened in the interim? Here the Court was at least frank: "The importance of the question, in which many states having similar laws are concerned, the close division by which the decision in the Adkins Case was reached, and the economic conditions which have supervened, and in the light of which the reasonableness of the exercise of the protective power of the state must be considered, make it not only appropriate, but we think imperative, that in deciding the present case the subject should receive fresh consideration." 10 The ban on minimum wage laws had been ignored and would be ignored. Adkins was flat out unenforceable. Something was wrong with the Court's jurisprudence when it issued decisions which could not, under any circumstances, be enforced. This linked West Coast Hotel with Marbury, in which the Court also refused to go along with a law which could not, under any circumstances, be enforced.

The case of United States v. Carolene Products Co., ${ }^{11}$ is famous for its footnote putatively exempting from the "minimum scrutiny" regime some facts in some contexts. But Carolene Products itself gives the lie to that "exemption." Carolene sustained a Federal policy preventing from interstate commerce, milk products with unwholesome substituted ingredients. But the Court here does not apply minimum scrutiny analysis. It treats as facts, "public health, morals, or welfare," 12 and sustains the law because it feels those are important facts. As the Court notes, state law permitting the shipment of such products, was not based on any facts relating the products to the policy permitting the shipment of them; the Court didn't care that there might be a state purpose. The facts were that the products had "been stripped of elements essential to the maintenance of health.... [The use of them] is generally injurious to health and facilitates fraud on the public," "13 the product marketed "in imitation or semblance of milk...."14 It has not been

\footnotetext{
${ }^{7}$ It need only be "conceivable." Hawaii Housing Authority v. Midkiff, 467 US 229, 241 (1984).

${ }^{8} 5$ US (1 Cranch) 137, 176 (1803).

${ }^{9} 261$ US 525 (1923).

${ }^{10}$ West Coast Hotel at 390.

11304 US 144 (1938).

${ }^{12} \mathrm{Id}$., at 147 .

${ }^{13} I d$., at 149 .

${ }^{14} I d$., at 151 .
} 
previously noted that the Court was able to intervene in this way because, in the first instance, in West Coast Hotel, its demotion of "liberty" was problematic.

Nevertheless, the Court in this case was busily working, laying the groundwork for an individually enforceable right to maintenance, in the following ways:

1. the fact was that the Federal Government had passed the ban on the substitute ingredients. Whatever previous law might have held this to be forbidden, the fact was that the Government was proceeding to enforce it. To overturn the ban would be to engage in the promulgation of unenforceable doctrines, which the Court had already found inadvisable in West Coast Hotel;

2. the Court held that "public health, morals, or welfare"-take your pick-are facts and the Government is proceeding to vindicate those facts;

3. the Court held that maintenance is an indicium of health, simply on the basis that the Government had passed the ban; and, finally,

4. the Court held that health is an indicium of maintenance.

The only remaining question was: where does liberty figure in all of this?.

One famous tenet of Carolene is that government needn't tailor its legislation precisely to facts. The Court attempted to make precise this imprecision. The Court said that "Appellee raises no valid objection to the present statute by arguing that its prohibition has not been extended to oleomargarine or other butter substitutes in which vegetable fats or oils are substituted for butter fat. The Fifth Amendment has no equal protection clause, and even that of the Fourteenth, applicable only to the states, does not compel their Legislatures to prohibit all like evils, or none. A Legislature may hit at an abuse which it has found, even though it has failed to strike at another." ${ }^{2}$ But this allowance for legislative "discretion" was inherently contradictory. On the one hand, "a statute would deny due process which precluded the disproof in judicial proceedings of all facts which would show or tend to show that a statute depriving the suitor of life, liberty, or property had a rational basis." 16 On the other, there "may be narrower scope for operation of the presumption of constitutionality when legislation appears on its face to be within a specific prohibition of the Constitution, such as those of the first ten Amendments" (this being the famous footnote). ${ }^{17}$ Since liberty had been "demoted" to minimum scrutiny, it was exempted from "narrower" operation-that is, the Court gave back to the political system that substituting of private for public purpose, which it seemed to have taken away. So what were, in fact, "narrow," "scope" and liberty? If the facts of "public health, morals, or welfare" enjoyed more scrutiny under the rubric of liberty, as did all legislative policies relating to them, it was anomalous that liberty itself enjoyed only minimum scrutiny. Thus, the Court's own factual findings began to force liberty once again to the surface-assuming, again, that it had ever submerged it. And what, for that matter, were, in fact, private health, morals and welfare?

\footnotetext{
${ }^{15} I d$., at 151 .

${ }^{16} \mathrm{Id}$., at 151 .

${ }^{17} I d$., at 155 (footnote 4).
} 
More specifically, what was the relationship between liberty and "public morals?" It took a brief sixty after Carolene Products, but that precise question was finally posed in Lawrence. The Lawrence case overturned Bowers v. Hardwick. ${ }^{18}$ In Bowers, the Court had sustained Georgia's law against sodomy as applied to two consenting adult males. What didn't Georgia like about sodomy?

\section{1. absoluteness combined with uncontrollability;}

It is sex, and any kind of sex: "any kind of private sexual conduct between consenting adults...."19 It's also "painful."20

\section{2. "phases;"}

It both is and is not, sex: "facetious." 21

\section{3. "history and connotation;"}

Georgia laws ban it and "have done so for a very long time.,"22

\section{4. and "evils which menace the health, safety, morals, and welfare of the people."}

It provides "[n]o connection between family, marriage, or procreation...."23

In short, Georgia didn't like sodomy because, for Georgia, sodomy was liberty. By the way, is it?

The point is that, as we can see from the criteria above, Georgia's criteria for liberty and its mandate regarding liberty came from the Supreme Court. For the Supreme Court, too, sodomy was liberty, and therefore had to be suppressed. The need for doing so "had [been] painfully demonstrated by the face-off between the Executive and the Court in the 1930's." ${ }^{24}$ This was Franklin Roosevelt's threat to pack the Court with more justices in order to get New Deal legislation found constitutional. And which branch of government, we ask, had suffered that pain? The Supreme Court. And how had the Court alleviated that curious pain? By sustaining, in West Coast Hotel, a minimum wage law in a tradeoff for the right to suppress liberty: again, the criteria listed above.

The law of privacy (one of those facts which the Court later felt should be exempt from the minimum scrutiny regime) is that it is an emanation of other Constitutional rights (the word "privacy" does not appear in the Constitution). If nothing else, the Lawrence Court ended this vagueness, vagueness being the fault which, more than anything else, has threatened the gains made under the rubric "privacy." Lawrence finally makes it clear that, whatever else privacy may be, it is a factual inquiry into

${ }^{18} 478$ US 186 (1986).

${ }^{19} I d$., at 191 .

${ }^{20} \mathrm{Id}$., at 194 .

${ }^{21} \mathrm{Id}$., at 194 .

${ }^{22} I d$., at 190 .

${ }^{23} I d$., at 191 .

${ }^{24}$ Id., at 194 . 
liberty. Thus, it is untenable to read Lawrence as increasing the number of facts called "privacy," and so granting them strict scrutiny, while that for which they are indicialiberty-remains at minimum scrutiny. This tension finally broke in favor of liberty, although it was clearly a tension. The particular point of stress at issue in DeShaney $v$. Winnebago County ${ }^{25}$ was whether government had an obligation to protect minors against parental abuse. Nevertheless, the Court took the opportunity to affirm that liberty remained only an unenforceable interest..

The Lawrence Court examined the facts as if liberty were a fact just like "public health, morals or welfare." Only, in this case, it found that the law didn't jibe with liberty. Among other things, as the Court noted, sodomy laws were unenforceable. The Lawrence Court brought back into the Constitution precisely that which the West Coast Hotel Court had exiled from the Constitution: liberty. It finally had unified its factual view of maintenance with its doctrinal view of liberty. Again, we are so new to this elevation of liberty and maintenance that we don't know what the United States Government must show in order to violate them. However, it is clear that both are now individually enforceable rights.

Perhaps it is giving the Court too much credit to say that, in West Coast Hotel, it did anything more recognizable than sustain a minimum wage law. The West Coast Hotel holding cannot be said to rise to the level of an opinion. It tilts at phantoms, most notably its bizarre notion of liberty, devoid of any reasoned conclusion. It is notable that the importance the Court gives to maintenance, it is careful not only to place in context, but also, to back up with facts. Perhaps if the Court had accorded the same treatment to liberty, it would not have taken seventy years to win the individually enforceable right to maintenance. Lawrence showed us that the scrutiny regime was so ill-founded, that we really have to go back to examine whether it has ever existed, ever been implemented, ever had any existence at all. We don't really know what predated it. Nor do we know what will succeed it. It is perhaps of a piece with the Court's bizarre jurisprudence, that the Lawrence Court, dealing as it does with liberty, doesn't even mention West Coast Hotel, although as we have seen, liberty is at the heart of the West Coast Hotel "holding." But when we do see the role of liberty in West Coast Hotel, the role of maintenance in Carolene Products, and then see the role of liberty in Lawrence, we can at least say this: whatever West Coast Hotel held, Lawrence has overruled it and given us maintenance as an individually enforceable right.

We live in a new era.

${ }^{25} 489$ US 189 (1989). 